\title{
Residential Customers Satisfaction with Public Water Provision in Ojota, Nigeria
}

\author{
Odafivwotu Ohwo \\ Tano Dumoyei Agusomu \\ Department of Geography and Environmental Management, \\ Niger Delta University, Wilberforce Island, Nigeria
}

Doi:10.19044/esj.2018.v14n23p117 URL:http://dx.doi.org/10.19044/esj.2018.v14n23p117

\begin{abstract}
Customer satisfaction is a good measure of the quality of service rendered by an enterprise. Hence, this study analyzed the perception of residential customers' satisfaction with public water provision in Ojota. The analyses was based on customers' perception of ten selected satisfaction drivers, which were obtained by the administration of a set of structured questionnaire, administered to 400 households, using the systematic sampling technique. The data was analyzed using percentages and a customer satisfaction index (CSI) model. The calculated CSI was 2.54 points on a 5 point scale, which means that public water provision in Ojota is perceive as fairly satisfactory by the residential customers. In addition, only $12.21 \%$ of the customers are willing to pay for water, based on their overall perception of the services of the Lagos Water Corporation (LWC). This shows that the service of the LWC to its customers is inadequate. It is therefore recommended that the LWC should undertake a general overhaul of its operations and improve on customer services, which may improve customers' willingness to pay for water provision and help the utility to improve on cost recovery and sustain adequate services to its customers.
\end{abstract}

Keywords: Customer Satisfaction, Lagos Water Corporation, Ojota, Water Provision

\section{Introduction}

Customer satisfaction with public water provision in Nigeria and most developing countries is still a great challenge due to several reasons such as poor budgetary allocations by the respective governments, ageing pipes resulting in frequent breaks, poor infrastructure investment, unstable power supply, unmotivated staff, poor revenue collection, urbanization, corruption and a highly politicized tariff setting regime (Gowela, Alleyne \& 
Chinopfukutwa, 2017; Ohwo, 2016a; Environmental Rights Action \& Friends of the Earth, Nigeria, 2016; LWC, 2013). This situation has impacted on the effectiveness and efficiency of some of the state water agencies (SWAs), which has made many urban inhabitants to be dissatisfied with their services as there are reported cases of supply of water of poor quality; intermittent supplies, low pressure and several days of no supply. Due to the poor level of service delivery, the affected SWAs are reluctant to increase water rates, and have also made customers to respond poorly to payment of bills leading to revenue losses by the affected SWAs (Ohwo, 2016a).

Customer satisfaction measurement enables an organization to undertake proper self evaluation and identify the key drivers that enhance its customers satisfaction. A global marketing information company (J. D. Power, 2016) states that the water industry faces ever-increasing needs for infrastructure investment, which makes customer support imperative. It therefore recommends that water utilities should be up to date regarding their customers' requirements and expectations. It further stated that utilities which understand their customers' behaviours, attitudes and preferences are better positioned to target performance initiatives that can increase overall customer satisfaction and garner support for infrastructure improvement. This assertion is supported by some empirical studies that have shown that there is a relationship between customers satisfaction and the willingness of customers to pay for water provision (Sualihu, Rahman \& Zakiya, 2017; Kayaga, Franceys \& Sansom, 2004). It is therefore imperative for water utilities to ensure that they satisfy thier customers, so that they can inturn support them by prompt payment for water provision, which would help the utilities to improve on cost recovery and sustain adequate services to its customers.

Over the years there has been an increase in the literature on different aspect of water provision, to avail policy makers with reliable information to take informed dicisions, which would lead to sustainable water provision by thier respective public water utilities. Some of these studies focused on access to improve sources of water supply, cost of water and quality and quantity issues (Ohwo \& Abotutu, 2014; Ohwo, 2014a; Wagah, Onyango \& Kibwage, 2010; Abaje, Ati \& Ishaya, 2009) with few focusing on the service quality of the respective public water providers, using customer perception of selected variables to determine customers satisfaction/dissatisfaction (Kassa \& Chernet, 2017; Gowela et al, 2017; Abubarka, 2016, Ojo, 2011). Some of the studies in the literature undertaken outside the study area have reported contrary results. For instance, the Washington Suburban Sanitary Commission and Maryland Marketing Source (2012) reported that after all considerations customers indicated moderate satisfaction with water supply and wastewater treatment services provided by the Washington Suburban Sanitary Commission. Another study in England and Wales by the Consumer Council 
for Water (2015) reported a 94\% customer satisfaction with water provision. In Africa, a study in Kenya by Karimi (2016) shows that the quality of water service delivery in Githurai was below average, using service level benchmarking; while a similar study in Abuja Nigeria by Ojo (2011) indicates that $63 \%$ of respondents living in the outskirts are satisfied with the quality of their water services, whereas those living in Phase 1 (low and medium density areas) was $71 \%$. This shows that there exists spatial inequality in water service provision by the water agency in Abuja.

The few studies undertaken on customer satisfaction with public water provision only focused on limited aspect of water service provision such as the quality and the cost of water service. However, no study has been found in the literature that focused on residential customers' satisfaction with public water provision in Ojota. In addition, this is the only study that has used customer perception of ten satisfaction drivers (five generic and five specific to the water utility industry) to measure customers level of satisfaction with the services of a public water provider (Lagos Water Corporation) using a customer satisfaction index (CSI) model. Information obtained from the analysis would enable the public water utility to identify its strenghts and weaknesses based on customers rating of the satisfaction drivers. This would enable the water utility agency to take informed decisions and make adjustments in its service provision strategies to improve on its services and enhance customer satisfaction. This would in turn improve its brand image, customers' loyalty and willingness to pay for water provision by its customers.

Since customer satisfaction is very important for the survival of any business enterprise, the aim of this study is to determine the performance rating of the Lagos Water Corporation (LWC) in terms of how well it satisfies its residential customers in Ojota. To achieve this aim the following are the research questions: What is the rating of LWC services by its residential customers in Ojota? What are the poorly rated satisfaction drivers? What is the level of customers willingness to pay for water provision based on their overall satisfaction of LWC services? Following this introduction is the literature review section. Next is the study area, method of study, results and discussion and conclusion.

\section{Literature Review}

\subsection{Concept of Customer Satisfaction}

Customer satisfaction may be defined as a state of fulfillment that customers have about a company's product or service after it has been used or experienced. Oliver (1997) defined customer satisfaction as a customer reaction to a state of fulfillment and the customer judgement of the fulfilled state. The quest to understand customer satisfaction had led to the development of theories such as the 'disconfirmation of expectations theory 
of consumer satisfaction' and the 'value-percept disparity model'. The disconfirmation of expectations model states that consumer responses to satisfaction or otherwise are based on a cognitive evaluation process in which pre-purchase "expectations" or prior beliefs of product-related experiences or outcomes are recalled from memory and compared to cognitions about the product-related experiences or outcomes actually obtained in the consumption of the product (Westbrook \& Reilly, 1983). On the other hand, the valueprecept disparity model, asserts that satisfaction/dissatisfaction is an emotional response, which results from a cognitive-evaluative process in which ones perception of an object, product or service is compared to one's values. The smaller the disparity between percepts of the product or service and one's values the more favourable the evaluation, which is indicative of satisfaction (Westbrook \& Reilly, 1983).

Customer satisfaction measurement enables an organization to undertake proper self evaluation and identify the key drivers that enhance customer satisfaction. Since customers' expectations act as a yardstick on which customers evaluate the quality of utility service delivery (Ojo, 2011), improving on customers' satisfaction drivers could improve the organization's competitive advantage, which could lead to increase sales, customer loyalty and sustainable profit, as documented in the literature (Bolton, 1998; Ralston, 1996).

Different methods (qualitative and quantitative) have been applied to measure customers' satisfaction with water provision by water utility agencies. Some of the studies (Zeraebruk, Mayabi, Gathenya \& Tsige, 2014; Al-Ghuraiz \& Enshassi, 2006) used questionnaire to obtain the needed information on customers' satisfaction with the services of a water utility provider, asking questions on selected customer satisfaction drivers, using the Likert scale, to determine the level of satisfaction to each of the selected drivers. In order to quantify customer satisfaction, some studies (Fattahi, Kherikhah, Sadeghian, Zandi \& Fayyaz, 2011; Fonseca, 2009) developed conceptual models which integrate the various selected satisfaction drivers to produce a single index for measuring satisfaction. For example, Fonseca (2009) used a conceptual model (overall satisfaction index) to measure customer satisfaction based on customers ratings of selected parameters on a scale of completely satisfied to completely dissatisfied. Since customers' evaluation of satisfaction is influenced by several factors, it is appropriate to use a satisfaction index to measure the overall judgment of the services rendered by a water utility agency. Hence, this study developed an additive model (customer satisfaction index), using ten selected satisfaction drivers to measure the quality of services rendered by LWC to its customers. Apart from generating an overall index for the assessment of the level of consumer satisfaction, the model also reveals the individual rating of the selected 
satisfaction drivers by the customers. This would assist the LWC to focus on its weaknesses and develop strategies to improve on them, which would enhance customer satisfaction.

\subsection{Water Provision and Customer Satisfaction}

The literature on water provision and customer satisfaction is increasing, since the realization that the continuous survival of any organization rest squarelly on the ability of the enterprise to satisfy its customers. The findings from these studies have revealed different levels of customers' satisfaction with their respective water utility providers. Most of the studies undertaken in developed economy reported higher levels of customer satisfaction, when compared to those carried out in developing nations. One of the major reasons for this state of affairs is perhaps the over concentration on increasing access to improve water sources at the detriment of quality service delivery in most developing countries. For instance, a study of the Monte Vista Water District on customers satisfaction in the USA revealed that majority $(89 \%)$ of residential retail customers indicated satisfaction with the District's efforts to provide water services, with $60 \%$ customers indicating very satisfied. Only $6 \%$ of the customers were dissatisfied; while 5\% were unsure or unwilling to state their opinion (Monte Vista Water District \& True North Research Inc., 2016). Another study carried out in England and Wales by the Consumer Council for Water (2015) reported a $94 \%$ customer satisfaction with water provision.

A similar customer survey conducted in Kenya, on the Naivasha Water and Sanitation Services (NAIVAWASS) revealved an overall customers service delivery satisfaction index of $59 \%$, with timeliness and fast procedure of serving customers identified as the major areas of weakness requiring improvements (Naivasha Water and Sanitation Services, 2014). Another study carried out in Africa by Kassa and Chernet (2017) on customer satisfaction in Southern Ethiopia, using a set of questionnaire based on the service quality (SERVQUAL) model, revealed that $47 \%$ of customers were satisfy with the services of the water provider, while $43 \%$ were dissatisfied with the services for various reasons. The report stated further that the customer satisfaction score was below the acceptable level for all service quality dimensions. In addition, the understanding of customers' communication, and responsiveness were far below the benchmark. In the same vein, Gowela et al (2017) also used a water SERVQUAL model to assess customer satisfaction with the services of Lilongwe Water Board, in Lilongwe, Malawi. The study reveals that customer expectations were not met as there were negative gap scores for all service quality dimensions. The overall results revealed that central zone had the widest gap score of -2.76 , while northern and southern zones have a gap score of -2.50 and -2.18 , respectively. The service quality dimensions with the 
widest gaps are reliability, responsiveness assurance and tangibles. The authors therefore stress the need for Lilongwe Water Board to improve its service delivery by focusing on the dimensions that have the widest gap, while taking into account those with nearest gap scores to achieve sustainable water supply.

A study in Asmara, Eritrea, on customer satisfaction with the quality of services by Asmara Water Supply Department (AWSD) carried out by Zeraebruka, Mayabib, Gathenyac and Tsige (2014) show similar trends as other studies carried out in Africa, as highlighted above. The study revealed that the quality of service rendered by AWSD to its customers was unsatisfactory, due to inadequate and non-equitable water distribution system, unreliable supply due to the rationing system, and poor management of water delivery services. The study further revealed that the quality of water service by ASWD in Asmara and surrounding villages fell below customers expectations and the level of dissatisfaction was as high as $60 \%$.

The poor services by respective water service providers in Africa affect the revenue drive by these agencies, because most customers are unwilling to pay for water provision due to poor services received from the water providers. This assertion is supported by Sualihu, Rahman and Tofik-Abu (2017) in their study of the payment behavior of water utility customers in the Greater Accra Region of Ghana, that customer satisfaction was the most significant direct predictor of the variation in the time taken to settle water bills. It is therefore imperative to undertake a study on customer satisfaction with public water provision in Ojota since no such study has been found in the literature.

\section{The Study Area}

Ojota is the headquarters of Kosofe Local Government Area of Lagos State. It is located within latitudes $6^{\mathrm{O}} 32^{\prime}$ and $6^{\mathrm{O}} 36^{\prime}$ North of the Equator and longitude $3^{\circ} 20^{\prime}$ and $3^{\circ} 23^{\prime}$ East of the Greenwich meridian (Figure 1). Ojota lies on a coastal plain with an average height of about $26 \mathrm{~m}$ above sea level. Ojota experiences two major seasons-rainy and dry, with an average annual rainfall of about $3000 \mathrm{~mm}$ and a mean monthly temperature of about $28^{\mathrm{O}} \mathrm{C}$. Ojota is a planned residential area with a heterogeneous population, which comprises of the Yorubas, Igbos, Urhobos, Hausas, non Nigerians etc. The National Population Commission (1991, Census) gave the population of Ojota as 37, 196 people, which comprises of 19, 706 males and 17, 490 females. Due to the strategic location of Ojota as the gateway to Lagos, the commercial headquarters of Nigeria; it has attracted people from all works of life, which has led to a steady increase in its population that is estimated to grow at an annual rate of 3\%. The 2017 projected population for Ojota was 80, 216 people, which comprises of 42, 498 males and 37, 718 females. 
The population of Ojota can be described as youthful, as it houses young men and women who are attracted to it to take advantage of the job and business opportunities it offers. Most of the people are engaged in commercial/business activities, civil service, top government administrators and those engaged in the organized private sector.

Ojota is well connected with a network of street roads and home to several religious, banking and educational institutions. Generally speaking, Ojota has a high building and population densities, which is majorly occupied by those in the medium economic class. However, a reasonable proportion of the population comprises of those in the low and high economic class of the society. This probably explains why Ojota is serviced by the Lagos Water Corporation (LWC). A large number of the population depends on the water corporation for her domestic and drinking water supply. Hence, people are seen carrying jerry cans in search of alternative water sources any time there is disruption of water supply from the LWC. This situation has caused a lot of inconveniences to households in Ojota, hence this study was designed to assess the perception of residential customers on the performance of the LWC. Ojota was chosen for this study because the findings would be a true representation of the quality of service rendered by the LWC, as it is one of the few areas in Lagos State that is extensively serviced by the water corporation.

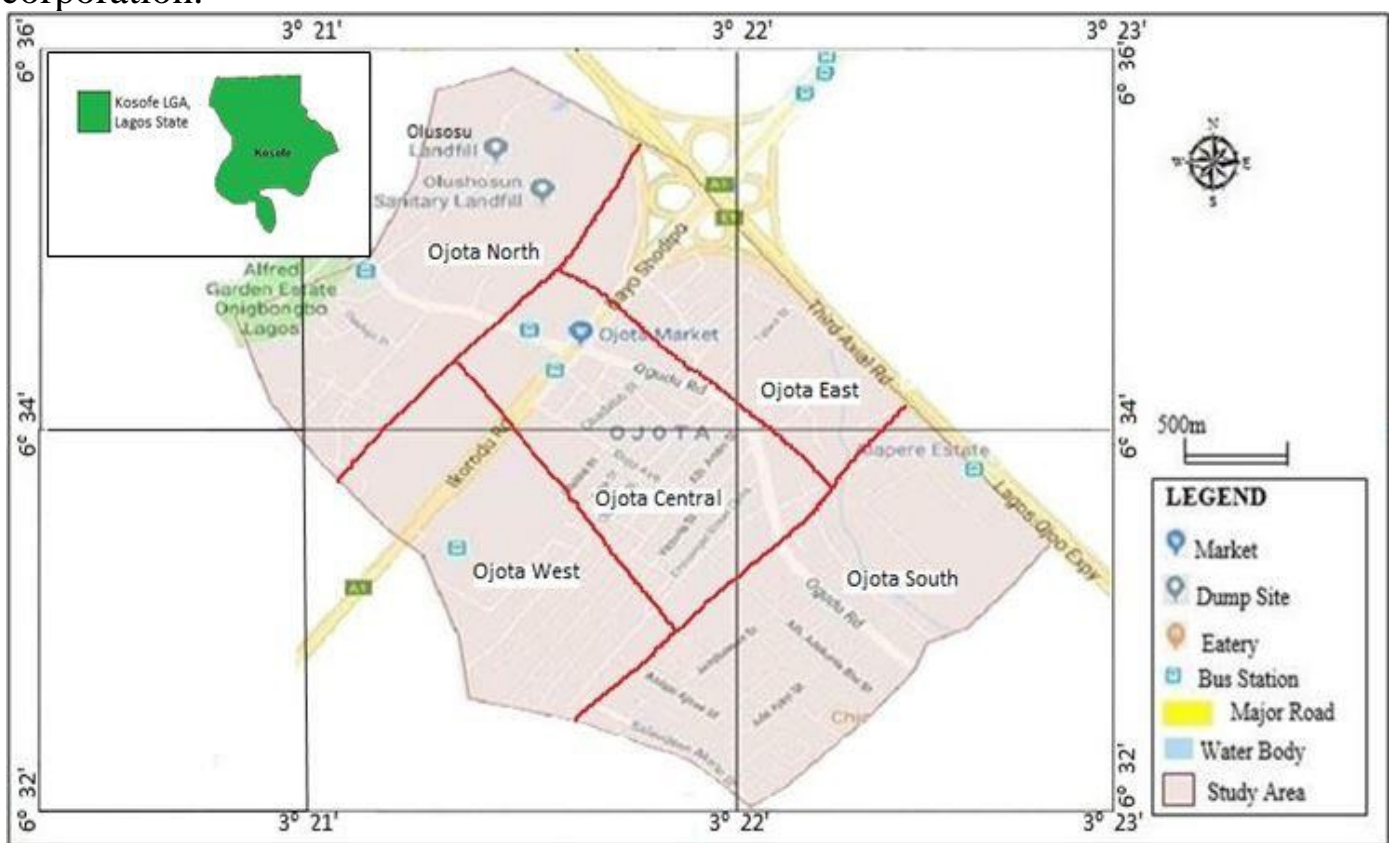

Figure 1: The Structured Zones in Ojota 


\section{Method of Study}

The aim of this study is to determine the performance rating of the Lagos Water Corporation (LWC) in terms of how well it satisfies its residential customers in Ojota. To achieve this aim the survey research method was adopted. This method involved the administration of a set of structured questionnaire, which was administered to residential customers of LWC, using the stractified and systematic sampling techniques. The population for the study consists of all residential customers of LWC in Ojota, from which a sample size of 400 residential customers was systematically selected for the study.

For a representative sample of the 400 residential customers, Ojota was structured into five zones, namely: Ojota North, Ojota South, Ojota East, Ojota West and Ojota Central (see Figure 1). This classification gives adequate representation of all segments of the population. In addition, this method was also adopted by Ohwo (2014a) and he achieved significant results. The 400 respondents were sampled from the five stractified zones and were assigned 80 sets of the questionnaire each in the absence of a reliable population figure of the respective zones, using the systematic sampling technique and fivehouse intervals. The questionnaire was administered directly by hand to the male or female household head that was available and willing to respond to the questionnaire with the aid of three trained research assistants. This was done to avoid the lost of questionnaire. In order to sample the 80 households in each of the zones, firstly, the streets in each zone were counted respectively; thereafter, eight streets were randomly selected and assigned 10 questionnaire each to make a total of 80 sets of questionnaire. In each of the sampled streets the first set of questionnaire was administered to the household in the first house, thereafter, a five-house interval was maintained until the 10 assigned sets of questionnaire were exhausted. The major limitation of this sampling method is that all the households in the respective zones may not have equal chances of being selected for the study.

Data for the study was obtained from the responses of the sampled 400 residential customers. The questionnaire consists of two sections: (a) demographic characteristics of respondents, and (b) customer satisfaction rating of the services of LWC by the respondents. Customer satisfaction rating was based on a 5-point Likert scale (very satisfied, satisfied, fairly satisfied, poorly satisfied and not satisfied). The Likert scale was used to assess customers' satisfaction with the services of LWC based on ten selected satisfaction drivers. The ten satisfaction drivers were obtained based on a survey of the literature on customer satisfaction.

A study conducted by the MORI Social Research Institute on behalf of the Office of Public Service Reform at the Cabinet Office in 2004, revealed five generic drivers of satisfaction with public services across the public 
sector, which include "delivery (the service delivers the outcome it promised and manages to deal with any problems that may arise), timeliness (the service responds immediately to the initial customer contact and deals with the issue at the heart of it quickly and without passing it on between staff), professionalism (staff are competent and treat customers fairly), information (the information given out to customers is accurate and comprehensive and they are kept informed about progress) and staff attitude (staff are friendly, polite and sympathetic to customers' needs)." These five generic satisfaction drivers were adopted and added to another five identified satisfaction drivers, which are peculiar to the water utility industry. These include water quality (physico-chemical and biological parameters within acceptable national and WHO standards; no colour, taste, odour, harmful chemicals and pathogens), water supply duration (water available at least 20 hours a day), water pressure and quantity (pressure is high enough to deliver at least 15 litres of water within five minutes), integrity of pipe network (pipes are well laid, no leaking or bust pipes, well maintained and of high quality) and cost of water (adequate billing and payment methods). These ten selected drivers of satisfaction in the water utility industry were rated by respondents using a 5-point Likert scale.

The data obtained were analyzed using descriptive statistics and a customer satisfaction index (CSI) additive model, which was adapted from a housing quality index (HQI) model designed by Ohwo (2014b). The model assessed the perceptual rating of customer satisfaction (CS) of the services of LWC by residential customers based on ten drivers of satisfaction. The customer satisfaction index (CSI) additive model is as follows:

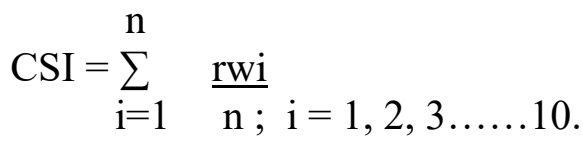

$$
\begin{aligned}
& \text { Where rwi }=\sum_{j=1}^{n}(\text { sj } x \text { nj) } \\
& \text { ti }
\end{aligned}
$$

CSI $=$ customer satisfaction index

rwi $=$ rating weight index for each satisfaction driver, a number between $1-5$

$\mathrm{sj}=\quad$ satisfaction unit weight, a number between 1-5

nj $=$ number of respondents to jth weight

ti $=$ total respondents to ith satisfaction driver

$\mathrm{n}=$ number of satisfaction drivers

$\sum=$ summation

The satisfaction unit weights are defined as follows: Very satisfied (5 points); satisfied (4 points); fairly satisfied (3 points); poorly satisfied (2 points); not satisfied (1 point). The CSI produce an overall numerical figure 
based on ten selected rating parameters (satisfaction drivers) that can be used to classify the level of customer satisfaction with the services rendered by a water utility. The scale is ranged from 1-5 points. The lowest value (1) means not satisfied, while the highest value (5) means very satisfied. For ease of interpretation, the customer satisfaction index (CSI) scale is as follows: very satisfied (4.50-5.00 points); satisfied (3.50-4.49 points); fairly satisfied (2.50-3.49 points); poorly satisfied (1.50-2.49 points); not satisfied (1.00 1.49 points).

\section{Results and Discussion}

\subsection{Demographic Characteristics of Respondents}

The number of questionnaires returned was $385(96.25 \%)$ out of the 400 administered. The demographic characteristics of respondents to the questionnaire are presented in Table 1. From the table the sex distribution revealed that $157(40.78 \%)$ respondents are males; while $228(59.22 \%)$ are females. However, the views of both sexes are well represented. The age distribution shows that the age bracket of 31-45years had the highest respondents (154) representing 40\%; while above 60years had the lowest figure of $38(9.87 \%)$. A similar pattern was also obtained by Ohwo (2016b) in his study of residents' perception of urban aesthetics of Yenagoa. The age distribution adequately captured the views of the adult population of Ojota.

The educational status of respondents shows that those with secondary education had the highest figure of 193 (50.13\%), while those with tertiary education were $145(37.66 \%)$ and those with no formal/primary education were $47(12.21 \%)$. This shows that the respondents are educated enough to understand the issues of public water provision in their respective households and to provide adequate responses. The income status of respondents' shows that the income bracket of N50, $000-\mathrm{N} 150,000$ had the highest responses (221) representing 57.40\%; while below N50, 000 had the lowest responses (57) representing $14.81 \%$ and above N150, 000 had 107 (27.79\%) respondents. This shows that the views of all the income strata (low, medium and high) in the population are well represented.

Table 1: Demographic Characteristics of Respondents

\begin{tabular}{|l|l|c|c|}
\hline $\begin{array}{l}\text { Questionnaire } \\
\text { Variable }\end{array}$ & $\begin{array}{l}\text { Response } \\
\text { Variable }\end{array}$ & $\begin{array}{c}\text { Number of } \\
\text { Respondents }\end{array}$ & $\begin{array}{l}\text { Percentage } \\
\text { Response (\%) }\end{array}$ \\
\hline \multirow{3}{*}{ Sex } & Male & 157 & 40.78 \\
\cline { 2 - 4 } & Female & 228 & 59.22 \\
\hline \multirow{4}{*}{ Age } & 18-30years & 77 & 20 \\
\cline { 2 - 4 } & 31-45years & 154 & 40.00 \\
\cline { 2 - 4 } & 46-60years & 116 & 30.13 \\
\cline { 2 - 4 } & Above 60 years & 38 & 9.87 \\
\hline \multirow{2}{*}{} & No formal/Primary & 47 & 12.21 \\
\cline { 2 - 4 } & Secondary & 193 & 50.13 \\
\hline
\end{tabular}




\begin{tabular}{|l|l|c|c|}
\hline $\begin{array}{l}\text { Educational } \\
\text { Qualification }\end{array}$ & Tertiary & 145 & 37.66 \\
\hline \multirow{3}{*}{ Monthly Income } & Below N50, 000 & 57 & 14.81 \\
\cline { 2 - 4 } & N50, 000- N150, 000 & 221 & 57.40 \\
\cline { 2 - 4 } & Above N150,000 & 107 & 27.79 \\
\hline
\end{tabular}

Source: Author's fieldwork, 2017

\subsection{Residential Customer Perception of Public Water Provision in Ojota}

The residential customer perception of public water provision in Ojota was determined by responses to ten selected satisfaction drivers (Table 2), which are relevant to the water utility corporation as defined in the method of study. Responses to the first satisfaction driver (water quality) indicate that $309(80.26 \%)$ respondents are either fairly, poorly or not satisfied with the quality of water from the public utility; while only 76 (19.74\%) are either very satisfied or satisfied (Table 2). One of the dissatisfied respondents states, "we don't even drink the water, it is not safe to drink it." The response pattern buttressed a study by Ohwo (2014a) that some of the tested water quality parameters of collected water samples at the respective zones for the study vary significantly from the samples collected at the premises of the water corporation and was above the WHO standards for potable water. He then concluded that the integrity of the water transported through the pipe distribution network is compromised, and water from the network is not safe for human consumption. Similar findings were reported in Nepal by Bhandari and Wickramanayake (2001) who observed that the water from the reservoir and intakes from most drinking water supply schemes were contaminated by pathogens, especially during the rainy season.

Responses to water supply duration were similar to that of water quality, as $309(80.26 \%)$ respondents were either fairly, poorly or not satisfied; while $76(19.74 \%)$ were either very satisfied or satisfied. Some of the interviewed respondents complained of irregular water supply and that there are some days without water supply. In spite of the irregular water supply to some of the households, the water pressure and quantity when supply is restored are unsatisfactory to majority of the respondents. For instance, only $27(7.02 \%)$ respondents considered the water pressure and quantity to be very satisfactory or satisfactory; while $358(92.98 \%)$ considered it to be either fairly, poorly or not satisfactory. One of the interviewed respondents stated that "water supply is not regular and when water is restored, in some cases it may take about 30 minutes to fill a 20 litre jerry can." These responses are in tandem with findings and submissions by past studies that the Lagos State Water Corporation over the years had failed to meet the increasing demands for water by its customers with a wide gap between demand and supply (Stimson Global Health Security, 2012; Ayeni, Omojola \& Fasona, undated). 
The integrity of the pipe network was also not favourably perceived by majority of the respondents, as $257(66.76 \%)$ respondents were either fairly satisfied $(33.25 \%)$, poorly satisfied $(28.57 \%)$ or not satisfied $(4.94 \%)$. However, $88(22.86 \%)$ and $40(10.39 \%)$ respondents were very satisfied and satisfied respectively. This response is a good reflection of the physical observation in the field as broken and leaking pipes were found in some locations. In addition, some respondents may have related the quality of their water supply to the poor state of the pipes. The response pattern however, confirm the findings of LWC (2013) that it suffers the lost of a large quantity of water through illegal connections, pipe leaks and burst pipes in the distribution systems, which has increased the quantity of water unaccounted for.

The realization of inadequate service provision by LWC and political considerations has probably made it difficult for the water corporation to charge economic rates. Hence, $320(83.11 \%)$ respondents are either very satisfied $(25.97 \%)$ or satisfied $(57.14 \%)$ with the cost of water. The percentages of respondents who are fairly satisfied $(7.27 \%)$, poorly satisfied (5.20\%) and not satisfied (3.42\%) are negligible as they all accounted for only $15.89 \%$. In fact, this was the only satisfaction driver that had the highest perception level. The LWC (2013) had reported that it has not been allowed by the State Government to charge water rates which would be sufficient to, at the very least, cover its operational cost. This clearly explains the low water rates paid by the residential customers in Ojota.

The perception of the five generic satisfaction drivers (delivery, timeliness, professionalism, information and staff attitude) applicable to any public utility agency do not fare better as over $85 \%$ of the respondents perceived these drivers as unsatisfactory. For instance, only 38 (9.88\%) respondents perceived service delivery by the water utility as satisfactory (very satisfied or satisfied); while $342(90.12 \%)$ respondents considered it as not too satisfactory (fairly satisfied, poorly satisfied or not satisfied), as they believed that the service by the water corporation failed to deliver the outcomes it promised and was unable to deal with some of the problems that arise. In the same vein, majority $(96.1 \%)$ of the respondents indicated that the timeliness of LWC to complaints and issues raised by customers is unsatisfactory. In fact, only $3.90 \%$ of the respondents perceived timeliness as satisfactory. A similar response pattern was recorded for professionalism, as $337(87.53 \%)$ and $48(12.47 \%)$ respondents perceived it as unsatisfactory and satisfactory, respectively. Some of the staff members of the LWC were perceived to be incompetent and are accused of unfair treatment of customers by the respondents.

Responses to both information dissemination and staff attitude were equally rated low just like other satisfaction drivers. For instance, 340 
(88.31\%) respondents perceived information dissemination by LWC as unsatisfactory (fairly satisfied, poorly satisfied or not satisfied); while only 45 $(11.69 \%)$ respondents rated it as satisfactory (very satisfied or satisfied). Some of the respondents complained of inadequacy or lack of information on supply schedules and interruptions by the corporation. Staff attitude to customers was perceived to be satisfactory by $61(15.84 \%)$ respondents, which comprise of $25(6.49 \%)$ responses as very satisfied and $36(9.35 \%)$ as satisfied; while a total of $324(84.16 \%)$ respondents are unsatisfied with staff attitude towards their customers. This comprises 165 (42.86\%), 64 (16.62\%) and 95 (24.68\%) responses to fairly satisfied, poorly satisfied and not satisfied, respectively. The findings from this study buttress the conclusion by Ojo (2011) that due to financial inadequacies and operational inefficiencies, the Federal Capital Territory (FCT) Water Board, Cross River State Water Board Limited and Lagos Water Corporation have failed to provide good quality service to their customers. Hence, responses to areas requiring improvement by the FCT Water Board show that $76 \%$ of the respondents would like to see an improvement in all areas of operations and customer service of the Water Board. This scenario mirrors what happens in other states of Nigeria. For instance, the African Development Bank Group (ADBG, 2013) reported that none of the existing state water utilities in Nigeria was able to provide uninterrupted water services to their citizens and many are among the worst performing in Africa due to weak institutional environment and lack of adequate maintenance system, which had led to rapidly decaying infrastructure.

Studies of public water utilities in other climes reported contrary findings to this study. For instance Baietti, Kingdom and Ginneken (2006) cited eleven case studies of public water utilities that cut across nations (developing and developed) and concluded that majority of the utilities, though monopolistic providers, are concerned about customer satisfaction and had taken some important measures such as friendliness of the customer billing and collection system, orientation toward seeking customers' opinions and views, availability of options for service delivery, timely information to customers on developments in relation to water services, and response to customers' complaints, which had improved customers service delivery by the affected water utilities.

\subsection{Customers' Willingness to Pay Water Rates}

Customers' willingness to pay water rates was determined based on their overall perception of satisfaction of the services offered by LWC. From Table 3, it was revealed that 99 (25.71\%), 111 (28.83\%) and $128(33.25 \%)$ respondents are not willing, poorly willing and fairly willing, respectively; while only $30(7.79 \%)$ and $17(4.42 \%)$ respondents are willing and very 
willing to pay respectively. One of the interviewed respondents stated that "even though the cost of water is low, am not encouraged to pay because we don't enjoy the services of the water corporation. It will be better to increase the cost of water and deliver quality services. This one is not good at all." This response pattern is in line with what is known from theory that satisfied customers would be more likely to pay what they are billed and to do so on time, which would result in higher collection ratio and prompt payment for water provision (Donkor, 2013).

Table 2: Residential Customer Perception of Public Water Provision in Ojota

\begin{tabular}{|c|c|c|c|c|c|c|}
\hline S/N & Satisfaction & $\begin{array}{c}\text { Very } \\
\text { Satisfied }\end{array}$ & Satisfied & $\begin{array}{c}\text { Fairly } \\
\text { Satisfied }\end{array}$ & $\begin{array}{c}\text { Poorly } \\
\text { Satisfied }\end{array}$ & $\begin{array}{c}\text { Not } \\
\text { Satisfied }\end{array}$ \\
\cline { 3 - 7 } & & $\begin{array}{c}\text { Response } \\
(\%)\end{array}$ & $\begin{array}{c}\text { Response } \\
(\%)\end{array}$ & $\begin{array}{c}\text { Response } \\
(\%)\end{array}$ & Response $(\%)$ & $\begin{array}{c}\text { Response } \\
(\%)\end{array}$ \\
\hline 1 & Water quality & 30 & 46 & 193 & 38 & 78 \\
& & $(7.79)$ & $(11.95)$ & $(50.13)$ & $(9.87)$ & $(20.26)$ \\
\hline 2 & Water supply & 28 & 48 & 126 & 106 & 77 \\
& duration & $(7.27)$ & $(12.47)$ & $(32.73)$ & $(27.53)$ & $(20.0)$ \\
\hline 3 & Water pressure & 10 & 17 & 118 & 230 & 10 \\
& and quantity & $(2.60)$ & $(4.42)$ & $(30.65)$ & $(59.74)$ & $(2.60)$ \\
\hline 4 & Integrity of pipe & 88 & 40 & 128 & 110 & 19 \\
& network & $(22.86)$ & $(10.39)$ & $(33.25)$ & $(28.57)$ & $(4.94)$ \\
\hline 5 & Cost of water & $100(25.97)$ & $220(57.14)$ & 28 & 20 & 17 \\
& & & & $(7.27)$ & $(5.20)$ & $(4.42)$ \\
\hline 6 & Delivery & 18 & 20 & 15 & 110 & 222 \\
& & $(4.68)$ & $(5.20)$ & $(3.90)$ & $(28.57)$ & $(57.66)$ \\
\hline 7 & Timeliness & 5 & 10 & 25 & 115 & 230 \\
& & $(1.30)$ & $(2.60)$ & $(6.49)$ & $(29.87)$ & $(59.74)$ \\
\hline 8 & Professionalism & 20 & 28 & 128 & 108 & 101 \\
& & $(5.20)$ & $(7.27)$ & $(33.25)$ & $(28.05)$ & $(26.23)$ \\
\hline 9 & Information & 18 & 27 & 98 & 115 & 127 \\
& & $(4.68)$ & $(7.01)$ & $(25.45)$ & $(29.87)$ & $(32.99)$ \\
\hline 10 & Staff attitude & 25 & 36 & 165 & 64 & 95 \\
& & $(6.49)$ & $(9.35)$ & $(42.86)$ & $(16.62)$ & $(24.68)$ \\
\hline
\end{tabular}

Source: Author's fieldwork, 2017

Table 3: Customer's Willingness to Pay Water Rates Based on Overall Perception of

Satisfaction

\begin{tabular}{|c|c|c|c|}
\hline S/N & Willingness to Pay Water Rates & Responses & Percentage (\%) \\
\hline 1 & Very willing & 17 & 4.42 \\
\hline 2 & Willing & 30 & 7.79 \\
\hline 3 & Fairly willing & 128 & 33.25 \\
\hline 4 & Poorly willing & 111 & 28.83 \\
\hline 5 & Not willing & 99 & 25.71 \\
\hline 6 & Total & 385 & 100 \\
\hline
\end{tabular}

Source: Author's fieldwork, 2017 


\subsection{Calculated Customers' Satisfaction Rating of Public Water Provision in Ojota}

Customers' satisfaction rating of public water provision in Ojota was determined using the data in Table 2. In order to determine the overall perception of customer satisfaction of public water provision in Ojota, the rating weight index (RWI) of each satisfaction driver was calculated and presented in Table 4, using equation 2 as shown in the method of study. The RWI is derived from the total of the calculated satisfaction unit weight (SJ) of the responses to each of the satisfaction drivers. The range of the calculated RWI of the satisfaction drivers was $1.57-3.95$ on a 5 point scale. The lowest value (1.57) was for timeliness and the highest value (3.95) was for cost of water. These values suggest that timeliness was the least rated of the satisfaction drivers; while cost of water was the best rated. The calculated customer satisfaction index (CSI) of 2.54 points on a 5 point scale was derived by the summation of the respective RWI for each of the satisfaction drivers and divided by the total number of the satisfaction drivers (10). With reference to the CSI scale as defined in the methodology, the calculated CSI value of 2.54 points means that residential customers of LWC perceived public water provision in Ojota as fairly satisfactory. This overall rating of the services of LWC by its residential customers in Ojota validates existing African scholarship/literature, that public water provision in most African countries is unsatisfactory (Gowela et al, 2017; Kassa \& Chernet, 2017; Zeraebruka et al, 2014)

In addition to the calculated overall perception by all respondents on customer satisfaction with public water provision in Ojota, the study also determines the impact of demographic characteristics of respondents on their perceptual rating. Personal characteristics of respondents, such as sex, age, education and income status were analyzed to determine their impact on the rating of public water provision in Ojota. The calculated RWI for public water provision by sex reveals that both the male and female respondents rated timeliness (1.53 and 1.58) and cost of water (3.91 and 3.97) as the lowest and highest satisfaction drivers respectively, with a CSI of 2.58 for males and 2.50 for females on a 5 point scale (Table 5). Although there was a slight variation in the ratings, the calculated CSI for both sexes fell within the fairly satisfactory rating. A similar trend was also recorded for age distribution ratings, where timeliness and cost of water were equally considered lowest and highest, respectively, across the various age groupings. The 60 years and above age group has the highest (2.76) CSI, while age 18 - 30 years group has the lowest (2.51) CSI (Table 5). However, all the CSI values across the age groupings are within the fairly satisfactory classification (2.50-3.49 points).

The calculated RWI for public water provision for education and income status are similar to sex and age ratings. For example, all the education 
and income status groupings rated timeliness as the lowest satisfaction driver, with a range of $1.43-1.81$; while cost of water was equally rated the highest satisfaction driver by respondents with medium and high income status and secondary and tertiary education, respectively, with a range of $3.93-4.20$. Those with no formal/primary education and low income status do not consider cost of water as the highest satisfaction driver based on the RWI of 2.96 and 3.21, respectively (Table 6). The probable reason is that most of those with no formal/primary education are low income earners who spend a high proportion of their income on water provision. Respondents with no formal/primary education have the highest CSI value (2.75), while those with tertiary education have the lowest CSI value of 2.41. On the other hand, respondents with low income status have the highest CSI value (2.73), while medium income earners have the lowest CSI value (2.47). In spite of the noticeable variations in the CSI values across the various respondents personal characteristics, all the values fell within the fairly satisfactory classification. The variations could be attributable to the experience, cognitive evaluation and expectation of the respondents. Since the overall ratings fell within the same classification scale (fairly satisfactory), it therefore means that public water provision in Ojota is inadequate.

Table 4: Calculated Overall Customers' Satisfaction Index of Public Water Provision in Ojota

\begin{tabular}{|c|c|c|c|c|c|c|c|}
\hline \multirow[t]{2}{*}{$\begin{array}{l}\mathrm{S} / \\
\mathrm{N}\end{array}$} & $\begin{array}{l}\text { Satisfaction } \\
\text { Drivers }\end{array}$ & $\begin{array}{c}\text { Very } \\
\text { Satisfi } \\
\text { ed } \\
\end{array}$ & Satisfied & $\begin{array}{c}\text { Fairly } \\
\text { Satisfied }\end{array}$ & $\begin{array}{c}\text { Poorly } \\
\text { Satisfied }\end{array}$ & $\begin{array}{c}\text { Not } \\
\text { Satisfied }\end{array}$ & \multirow{2}{*}{$\begin{array}{c}\text { Rating } \\
\text { weight index } \\
\text { of each } \\
\text { satisfaction } \\
\text { driver (rwi) }\end{array}$} \\
\hline & & $\begin{array}{c}\text { Unit } \\
\text { weigh } \\
\mathrm{t}(5) \\
\end{array}$ & $\begin{array}{c}\text { Unit } \\
\text { weight (4) }\end{array}$ & $\begin{array}{c}\text { Unit } \\
\text { weight } \\
(3)\end{array}$ & $\begin{array}{c}\text { Unit } \\
\text { weight } \\
(2)\end{array}$ & $\begin{array}{c}\text { Unit } \\
\text { weight } \\
(1)\end{array}$ & \\
\hline 1 & Water quality & 0.39 & 0.48 & 1.50 & 0.20 & 0.20 & 2.77 \\
\hline 2 & $\begin{array}{l}\text { Water supply } \\
\text { duration }\end{array}$ & 0.36 & 0.50 & 0.98 & 0.55 & 0.20 & 2.59 \\
\hline 3 & $\begin{array}{l}\text { Water pressure } \\
\text { and quantity }\end{array}$ & 0.13 & 0.18 & 0.92 & 1.20 & 0.03 & 2.46 \\
\hline 4 & $\begin{array}{l}\text { Integrity of pipe } \\
\text { network }\end{array}$ & 1.14 & 0.42 & 1.00 & 0.57 & 0.05 & 3.18 \\
\hline 5 & Cost of water & 1.30 & 2.29 & 0.22 & 0.10 & 0.04 & 3.95 \\
\hline 6 & Delivery & 0.23 & 0.21 & 0.12 & 0.57 & 0.58 & 1.71 \\
\hline 7 & Timeliness & 0.07 & 0.10 & 0.20 & 0.60 & 0.60 & 1.57 \\
\hline 8 & Professionalism & 0.26 & 0.29 & 1.00 & 0.56 & 0.26 & 2.37 \\
\hline 9 & Information & 0.23 & 0.28 & 0.76 & 0.60 & 0.33 & 2.20 \\
\hline 10 & Staff attitude & 0.33 & 0.37 & 1.29 & 0.33 & 0.25 & 2.57 \\
\hline
\end{tabular}

Source: Author's fieldwork, 2017 $\sum$ rwi $=25.37$

$$
\mathrm{CSI}=\sum_{\mathrm{i}=1}^{\mathrm{n}} \frac{\mathrm{rwi}}{\mathrm{n} ;}=25.37=\mathbf{2 . 5 4} \text { points }
$$


Table 5: Calculated Customers' Satisfaction Index for Public Water Provision in Ojota by Sex and Age

\begin{tabular}{|c|c|c|c|c|c|c|c|}
\hline \multirow[t]{3}{*}{$\mathrm{S} / \mathrm{N}$} & \multirow[t]{3}{*}{ Satisfaction Drivers } & \multicolumn{6}{|c|}{$\begin{array}{l}\text { Calculated Rating Weight Index for each Satisfaction Driver } \\
\text { (RWI) }\end{array}$} \\
\hline & & \multicolumn{2}{|c|}{ Sex } & \multicolumn{4}{|c|}{ Age } \\
\hline & & Male & Female & $\begin{array}{l}18- \\
30 \mathrm{yrs}\end{array}$ & $\begin{array}{l}31- \\
45 \mathrm{yrs}\end{array}$ & $\begin{array}{l}46- \\
60 \mathrm{yrs}\end{array}$ & $\begin{array}{l}\text { Above } \\
60 \mathrm{yrs}\end{array}$ \\
\hline 1 & Water quality & 3.06 & 2.57 & 2.41 & 3.24 & 2.67 & 2.77 \\
\hline 2 & Water supply duration & 2.82 & 2.46 & 2.39 & 2.66 & 2.55 & 2.92 \\
\hline 3 & $\begin{array}{l}\text { Water pressure and } \\
\text { quantity }\end{array}$ & 2.52 & 2.41 & 2.41 & 2.43 & 2.43 & 2.74 \\
\hline 4 & $\begin{array}{c}\text { Integrity of pipe } \\
\text { network }\end{array}$ & 3.28 & 3.12 & 3.00 & 3.18 & 3.25 & 3.29 \\
\hline 5 & Cost of water & 3.91 & 3.97 & 3.76 & 3.99 & 4.09 & 3.77 \\
\hline 6 & Delivery & 1.63 & 1.76 & 1.79 & 1.62 & 1.70 & 1.98 \\
\hline 7 & Timeliness & 1.53 & 1.58 & 1.69 & 1.46 & 1.50 & 1.95 \\
\hline 8 & Professionalism & 2.43 & 2.34 & 2.42 & 2.31 & 2.30 & 2.70 \\
\hline 9 & Information & 2.18 & 2.22 & 2.29 & 2.12 & 2.22 & 2.41 \\
\hline 10 & Staff attitude & 2.47 & 2.62 & 2.96 & 2.31 & 2.47 & 3.08 \\
\hline 11 & Calculated CSI & 2.58 & 2.50 & 2.51 & 2.53 & 2.52 & 2.76 \\
\hline
\end{tabular}

Source: Author's fieldwork, 2017

Table 6: Calculated Customers' Satisfaction Index of Public Water Provision in Ojota by Education and Income Status

\begin{tabular}{|c|c|l|l|l|l|l|l|}
\hline S/N & Satisfaction Drivers & \multicolumn{3}{|l|}{$\begin{array}{l}\text { Calculated Rating Weight Index for each Satisfaction Driver } \\
\text { (RWI) }\end{array}$} & \multicolumn{2}{|c|}{ Education Status } & \multicolumn{3}{c|}{ Income Status } \\
\hline & & $\begin{array}{l}\text { No } \\
\text { formal/Pr } \\
\text { imary }\end{array}$ & Sec. & Ter. & Low & Medium & High \\
\hline 1 & Water quality & 3.16 & 2.92 & 2.45 & 3.62 & 2.84 & 2.96 \\
\hline 2 & Water supply duration & 3.10 & 2.63 & 2.39 & 2.86 & 2.51 & 2.57 \\
\hline 3 & Water pressure and & 2.40 & 2.46 & 2.39 & 2.46 & 2.41 & 2.49 \\
\hline 4 & $\begin{array}{c}\text { Integrity of pipe } \\
\text { network }\end{array}$ & 3.18 & 3.38 & 2.91 & 3.62 & 3.10 & 3.09 \\
\hline 5 & Cost of water & 2.96 & 4.01 & 4.20 & 3.21 & 3.93 & 4.39 \\
\hline 6 & Delivery & 2.35 & 1.67 & 1.56 & 2.02 & 1.58 & 1.78 \\
\hline 7 & Timeliness & 1.71 & 1.63 & 1.43 & 1.81 & 1.48 & 1.59 \\
\hline 8 & Professionalism & 2.62 & 2.33 & 2.35 & 2.45 & 2.36 & 2.35 \\
\hline 9 & Information & 2.82 & 2.21 & 2.01 & 2.52 & 2.07 & 2.32 \\
\hline 10 & Staff attitude & 3.20 & 2.52 & 2.41 & 2.76 & 2.45 & 2.70 \\
\hline 11 & $\begin{array}{c}\text { Customer Satisfaction } \\
\text { Index (CSI) }\end{array}$ & 2.75 & 2.58 & 2.41 & 2.73 & 2.47 & 2.62 \\
\hline & & & & & & \\
\hline
\end{tabular}

Source: Author's fieldwork, 2017 


\section{Conclusion}

Public water provision by the LWC is perceived to be inadequate by residential customers' in Ojota, based on their ratings of ten selected satisfaction drivers. Timeliness of service by the LWC to it's customers' complaints was the least rated (1.57 points) of the satisfaction drivers; while the cost of water was the best rated (3.95 points) on a 5 point scale, because majority of the respondents believed that the cost of water was adequate. In spite of the favourable rating for cost of water, however, only $12.21 \%$ of the customers are willing to pay for water based on their overall perception of the quality of LWC services. The overall calculated customers' satisfaction index (CSI) was 2.54 points, which means that public water provision in Ojota was rated as fairly satisfactory by the residential customers. In addition, the rating based on the socio-demographic characteristics of the customers produced similar results with the overall ratings, which also fell within the fairly satisfactory classification. This means that the service of LWC to its customers is inadequate and much improvement is required.

The study revealed that five out of the ten satisfaction drivers have a calculated RWI of less than 2.50 (50\%), which means that these drivers (timeliness, delivery, information, professionalism, water pressure and quantity) presented in the order of least rating, accounted significantly to the overall poor rating by the customers. Based on this findings, the LWC should undertake a general overhaul of its operations, with particular attention paid to the five least rated satisfaction drivers. The corporation should also set up quality assurance monitoring unit to interface with its customers and the different departments/units in the corporation. Since customers generally rated the cost of water as low, the corporation should marginally increase its water rate to improve on its cost recovery. However, this should only be done when there is a significant improvement in its overall customer services, particularly on the five least rated satisfaction drivers. These measures would improve the corporation's image, customer loyalty, customers' willingness to pay for water provision and overall customer satisfaction. This study recommends that a similar study should be carried out on industrial and commercial customers' satisfaction with the services of LWC and other water utility corporations in Nigeria. The implementation of recommendations from such studies would enhance the quality of public water delivery and help to achieve the sustainable development goals (SDGs) for water in Nigeria.

\section{References:}

1. Abaje, I. B; Ati, O. F and Ishaya, S (2009) Nature of Potable Water Supply and Demand in Jema'a Local Government Area of Kaduna State, Nigeria, Research Journal of Environment and Earth Sciences, 1(1): 16-21 
2. Abubakar, I. R (2016) Quality Dimensions of Public Water Services in Abuja, Nigeria, Utilities Policy, 38: 43-51

3. African Development Bank Group (2013) Urban Water Sector Reform and Port Harcourt Water and Sanitation Project, Environmental and Social Impact Assessment and Resettlement Action Plan Summary.

4. Al-Ghuraiz, Y. and Enshassi, A (2006) Customers' Satisfaction with Water Supply Service in the Gaza Strip, Building and Environment, 41: 1243-1250.

5. Ayeni A. O, Omojola, A. S and Fasona, M. J (Undated) Urbanization and Water Supply in Lagos State, Nigeria: The Challenges in a Climate Change Scenario

[Online] http://www.iwra.org/congress/resource/PAP005503.pdf [Accessed Jan. 05, 2018]

6. Baietti, A, Kingdom, W and Ginneken, M. V (2006) Characteristics of Well-Performing Public Water Utilities, Water Supply \& Sanitation Working Notes, No. 9, May 2006 Water Supply and Sanitation Sector Board of the Infrastructure Network of the World Bank Group.

7. Bhandari, B. and Wickramanayake, B. (2001) Community Management and Water Quality in Rural Water Supply System in Nepal, Asia-Pacific Journal of Rural Development 10 (2):53-67

8. Bolton, R.N. (1998) A Dynamic Model of the Duration of the Customer's Relationship with a Continuous Service Provider: The Role of Satisfaction, Marketing Science, 17(1): 44-65.

9. Customer Council for Water (2015) Water Matters: Households Customers'Views on their Water and Sewerage Services 2014, Executive Summary

10. Donkor, E. A (2013) Effect of Customer Satisfaction on Water Utility Business Performance, Journal of American Water Works Association, 553-560, http://dx.doi.org/10.5942 / jawwa.2013.105.0114

11. Environmental Rights Action/Friends of the Earth, Nigeria (2016) Lagos Water Crisis: Alternative Road Map for Water Sector

12. Fattahia, P, Kherikhaha, A, Sadeghiana, R Zandib, S and Fayyaza, S (2011) An Evaluation Model for Measuring Customer Satisfaction Levels in a Water Supply Domain: Case Study - Water Supply in Hamedan, Water Policy 13: 490-505 doi:10.2166/wp.2010.123

13. Fonseca, J. R. S. (2009) Customer Satisfaction Study via a Latent Segment Model, Journal of Retailing and Consumer Services, 5: 352359.

14. Gowela, J. J, Alleyne, T and Chinopfukutwa, G. L (2017) Service Quality Gap Analysis to Improve Public Water Service Delivery in Lilongwe City: Tapping Customer's Voice, Journal of Environment and Earth Science Vol.7, No.4: 117-128 
15. J. D. Power (2016) Water Utility Residential Customer Satisfaction Study, A Global Marketing Information Company, http://india.jdpower.com/sites/default/files/jdpower_waterutilityResid entialcustomersatstudy_brochure_16pdf

16. Karimi, A. N (2016) Assessment of the Quality of Water Service Delivery in Peri Urban Kenya: Case Study of Githurai, Nairobi, A Master Degree Dissertation in Integrated Water Resources Management (MIWRM), University of Dar es Salaam

17. Kassa, K and Chernet, M (2017) Customer Satisfaction Survey: The Case of Urban Water Supply Services in Southern Ethiopia, Water Practice \& Technology 12(4):1009-1017, DOI:10.2166/wpt.2017.105

18. Kayaga, S., Franceys, R. and Sansom, K (2004) Bill Payment Behaviour in Urban Water Services: Empirical Data from Uganda, Journal of Water Supply: Research and Technology - Aqua, 53 (5): 339 - 349.

19. Lagos Water Corporation (2013) Stakeholders/CSO Interaction with LWC [Online] www.Lagoswater.org/news.php?page=51 (Accessed October 12, 2014).

20. Monte Vista Water District and True North Research (2016) Residential Customer Survey, Report Summary

21. Naivasha Water and Sewerage Services (2014) Customer Satisfaction and Perception Survey, Final Report

22. Ohwo, O (2014a) The Impact of Pipe Distribution Network on the Quality of Tap Water in Ojota, Lagos State, Nigeria, American Journal of Water Resources, Vol. 2 (5): 110-117

23. Ohwo, O (2014b) Housing Quality in Yenagoa, Bayelsa State, Nigeria, Nigerian Geographical Journal, New Series, Vol. 10 (1): 53-67

24. Ohwo, O (2016a) Challenges of Public Water Provision in Nigerian Cities: A Review, Journal of Water, Sanitation and Hygiene for Development, 06.1: 1-12

25. Ohwo, O (2016b) Residents' Perception of Urban Aesthetics of Yenagoa, Bayelsa State, Nigerian, Geography Journal, New Series, Vol. 11 No. 1: 93-104

26. Ohwo, O and Abotutu, A. (2014) Access to Potable Water Supply in Nigerian Cities: Evidence from Yenagoa, Metropolis, American Journal of Water Resources, Vol. 2, No. 2: 31-36. doi: 10.12691/ajwr2-2-1

27. Ojo, V. O (2011) Customer Satisfaction: A Framework for Assessing the Service Quality of Urban Water Service Providers in Abuja, Nigeria, Ph.D Thesis, School of Civil and Building Engineering Loughborough University, Loughborough 
28. Oliver, R.L., (1997) Satisfaction: A Behavioral Perspective on the Consumer, in McMullan, Rosalind \& Gilmore, Audrey (2003), The Conceptual Development of Customer Loyalty Measurement: A Proposed Scale", Journal of Targeting, Measurement and Analysis for Marketing, Vol.11, No 3: 230-243

29. Ralston, R. W (1996) Models Maps Out Sure Path to Growth in Marketplace, Marketing News, 30 (11): 12.

30. Stimson Global Health Security," Lagos: Growth without infrastructure," The Stimson Centre, 2012 [Online], Available: http://www.stimson.org, [Accessed Jul. 24, 2013]

31. Sualihu,M. A, Rahman, M. A and Tofik-Abu, Z (2017) The Payment Behavior of Water Utility Customers in the Greater Accra Region of Ghana: An Empirical Analysis SAGE Open: 1-12 DOI: $10.1177 / 2158244017731494$

32. Wagah, G, Onyango, G and Kibwage, J (2010) Accessibility of Water Services in Kisumu Municipality, Kenya, Journal of Geography and Regional Planning, Vol. 3(4): 114-125

33. Washington Suburban Sanitary Commission and Maryland Marketing Source Incorporated (2012) Customer Satisfaction Study \& Focus Groups (No. 1046) Executive Summary Reports

34. Westbrook, R. A and Reilly, M. D (1983) Value-Percept Disparity: An Alternative to the Disconfirmation of Expectations Theory of Consumer Satisfaction, Advances in Consumer Research Volume 10: 256-261

35. Zeraebruk, K. N, Mayabi, A. O, Gathenya, J. M and Tsige, Z (2014) Assessment of Level and Quality of Water Supply Service Delivery for Development of Decision Support Tools: Case Study Asmara Water Supply International Journal of Sciences: Basic and Applied Research (IJSBAR) Volume 14, No 1: 93-107 